\title{
MENINGKATKAN HASIL BELAJAR MATEMATIKA MATERI FUNGSI KUADRAT MENGGUNAKAN APLIKASI GOOGLE CLASSROOM DI KELAS IX.2 SMP NEGERI 18 KOTA BENGKULU SEMESTER GANJIL TAHUN PELAJARAN 2020 / 2021
}

\author{
Nurhasnah \\ SMP Negeri 18 Kota Bengkulu \\ nurhasna890@gmail.com
}

\begin{abstract}
Abstrak
Penelitian ini bertujuan untuk meningkatkan hasil belajar pada mata pelajaran matematika dengan menggunakan Aplikasi Google Classroom pada siswa kelas IX.2 SMP Negeri Kota Bengkulu yang berjumlah 28 siswa, terdiri dari 23 siswa laki-laki dan 5 siswa perempuan. Teknik pengumpulan data menggunakan observasi, tes, dan dokumentasi. Teknik analisis data dilakukan melalui model dengan urutan : reduksi data, penyajian data, dan penarikan kesimpulan. Hasil penelitian ini adalah meningkatnya hasil belajar siswa pada pembelajaran matematika. Hal ini dapat dilihat dari peningkatan presentase hasil belajar siswa dari sebelum tindakan, siklus I sampai siklus II. Pada pra siklus jumlah siswa yang mencapai KKM adalah $42,9 \%$ atau 12 siswa, meningkat 21,4\% pada siklus I menjadi 64,3\% atau 18 siswa. Pada siklus II jumlah siswa yang mencapai KKM meningkat sebanyak $17 \%$ menjadi $82,1 \%$ atau 23 siswa. Dengan demikian dapat disimpulkan bahwa penggunaan aplikasi Google Classroom dapat meningkatkan hasil belajar pada mata pelajaran matematika dikelas.
\end{abstract}

Kata Kunci: matematika, hasil belajar, google classroom

\begin{abstract}
This study aims to improve learning outcomes on mathematics subjects by using the Google Classroom Application in class IX.2 SMP Negeri Kota Bengkulu, amounting to 28 students, consisting of 23 male and 5 female students. The technique of collecting data uses observation, tests, and documentation. Data analysis techniques are carried out through models in order: data reduction, data presentation, and conclusion drawing. The results of this study are increasing student learning outcomes in mathematics learning. This can be seen from the increase in the percentage of student learning outcomes from the pra siklus, siklus I to siklus II. In the pra siklus the number of students who reached the KKM was $42,9 \%$ or 12 students, an increase of $21,4 \%$ in the siklus I to $64,3 \%$ or 18 students. In the siklus II the number of students who achieved KKM increased by $17 \%$ to $82,1 \%$ or 23 students. This it can be concluded that the use of the Google Classroom application can improve learning outcomes in mathematics subjects in class IX.2 SMP Negeri Kota Bengkulu 2020/2021.
\end{abstract}

Keywords: mathematics, learning outcomes, google classrom

\section{PENDAHULUAN}

Belajar adalah kunci yang sangat penting dalam setiap usaha pendidikan. Pendidikan suatu hal yang sangat penting bagi kehidupan manusia dalam rangka mencerdaskan kehidupan bangsa. Pendidikan mempunyai peranan yang penting dalam memperbaiki kualitas sumber daya manusia. Di dalam UndangUndang No. 20 Tahun 2003 tentang sistem pendidikan nasional bahwa:

"Pendidikan adalah usaha sadar dan terencana untuk mewujudkan suasana belajar dan proses pembelajaran agar peserta didik secara secara aktif mengembangkan potensi dirinya untuk memiliki kekuatan spiritual keagamaan, pengendalian diri, kepribadian, kecerdaasan, akhlak mulia, serta keterampilan yang diperlukan dirinya, masyarakat, bangsa dan negara".

Hasil belajar mempunyai peranan penting dalam proses pembelajaran. Menurut Kayatun (2014) hasil belajar 
merupakan hasil yang diperoleh peserta didik setelah terjadinya proses pembelajaran yang ditunjukkan dengan nilai tes yang diberikan oleh guru setiap selesai memberikan materi pembelajaran pada satu pokok bahasan. Selain hasil belajar Keaktifan siswa juga perlu diperhatikan dalam proses pembelajaran. Proses pembelajaran sangat memerlukan keaktifan siswa, tanpa adanya keaktifan siswa maka pembelajaran terkesan membosankan. Menurut Annurahman (2009: 119) menyatakan keaktifan siswa dalam belajar merupakan persoalan penting dan mendasar yang harus dipahami, dan dikembangkan setiap guru dalam proses pembelajaran. Sehingga keaktifan siswa perlu digali dari potensi-potensinya, yang mereka aktualisasikan melalui aktifitasnya untuk mencapai tujuan pembelajaran.

Dalam pembelajaran matematika banyak metode mengajar yang dapat digunakan, namun tidak setiap metode mengajar cocok dengan materi pokok bahasan yang diajarkan. Berbagai media dan metode yang dipakai oleh guru seperti metode ceramah, penggunaan power point, diskusi dan tanya jawab rupanya masih kurang dalam memfasilitasi siswa untuk belajar lebih serius khususnya belajar matematika. Perkembangan teknologi informasi dan kounikasi di era industri telah memiliki pengaruh besar terhadap proses pembelajaran. Menurut Keengwe \& Georgina (2012) dalam penelitiannya menyatakan bahwa perkembangan teknologi memberikan perubahan terhadap proses pengajaran dan pembelajaran. Internet yang semakin luas dan canggih sebagai alat sarana untuk mempermudah pembelajaran. Pembelajaran berbasis daring (online) dibutuhkan sebagai sarana atau alat untuk pendukung proses pembelajaran saat ini. Salah satu media teknologi yang sering digunakan saat ini adalah aplikasi pada telepon genggam/ponsel. Hasil penelitian Gheytasi et al., (2015) menunjukan bahwa siswa yang banyak berinteraksi dengan aplikasi di telepon genggam lebih mudah memahami isi teks bacaan. Banyak berbagai macam media pembelajaran yang ada namun belum digunakan guru secara maksimal. Salah satunya adalah penggunaan media aplikasi google classroom dapat dimanfaatkan sebagai media pembelajaran untuk membantu meningkatkan hasil belajar siswa.

Desain dari Google Classroom sudah tidak asing lagi bagi siswa karena mereka sudah menggunakan beberapa produk dari Google via akun Google Apps (Izenstark \& Leahy, 2015). Penggunaan Google Classroom ini sesungguhnya mempermudah guru dalam mengelola pembelajaran dan menyampaikan informasi secara cepat dan akurat kepada siswa (Hardiyana, 2015). Google Classroom di desain untuk empat pengguna yaitu pengajar, siswa, wali dan administrator. Kelebihan aplikasi Google Classroom dibandingan dengan aplikasi lain yaitu aplikasi Google Classroom dapat digunakan untuk membuat dan mengelola kelas, tugas, nilai serta memberikan masukan secara langsung. Siswa dapat memantau materi dan tugas kelas, berbagi materi dan berinteraksi dalam kelas atau melalui email, mengirim tugas dan mendapatkan masukan nilai secara langsung. Pembelajaran dengan penggunaan Google Classroom ini memiliki kelebihan untuk mempermudah siswa dalam belajar. Berdasarkan jurnal penelitian Abd Rozak dan Azkia M. Albantani (2018) yang berjudul "Desain Perkuliahan Bahasa Arab Melalui Google Classroom" menyimpulkan bahwa dalam proses pembelajaran bahasa arab melalui Google Classroom memberikan kemudahan bagi mahasiswa dan dosen dalam proses perkuliahan karena adanya jalinan komunikasi secara langsung dan jelas, terutama komunikasi tugas mengenai tugas dan materi yang disampaikan. Dengan adanya aplikasi google classroom ini diharapakan mempermudah siswa untuk belajar sehingga dapat meningkatkan hasil belajarnya.

Dari hasil penelitian-penelitian tersebut, peneliti berupaya melakukan inovasi media belajar untuk pembelajaran matematika di kelas IX.2 SMP Negeri 18 kota Bengkulu . Hasil wawancara dengan guru matematika menyimpulkan bahwa masih ada masalah pada hasil belajar siswa. Berdasarkan nilai tes, lebih dari 50\% siswa 
yang memperoleh nilai di bawah kriteria ketuntasan minimal. Hal tersebut dikarenakan banyak siswa mengalami kesulitan dalam belajar, waktu belajar siswa masih kurang, dan kurangnya minat siswa dalam membaca buku dan mengerjakan latihan soal.

Dari hasil wawancara dengan guru mata pelajaran matematika, selama ini proses pembelajaran belum menggunakan teknologi yang bisa membantu proses pembelajaran, contohnya dengan pembelajaran berbasis daring. Padahal dengan penggunaan media pembelajaran berbasis daring inilah dapat mempermudah guru dalam kegiatan pembelajaran dan mempermudah siswa dalam belajar. Oleh karena itu, penelitian ini telah menyajikan metode pembelajaran berbasis daring yaitu penggunaan aplikasi google classroom untuk membantu disetiap proses peembelajaran. Hal ini disebabkan karena hampir semua siswa memiliki telepon genggam untuk mengakses aplikasi google classroom. Google classromm adalah aplikasi yang dikembangkan oleh perusahaan google. Dengan adanya aplikasi ini pengajar dan siswa dari sekolah manapun bisa berkomunikasi dengan cara yang jauh lebih sederhana. Salah satu kekuatan google classroom yaitu memungkinkan penghematan kertas karena pekerjaan atau dokumen yang digunakan di kelas akan dibagikan secara digital. selain mudah diguanakan di aplikasi google classroom ini menyajikan berbagai macam fitur yang mendukung pada proses kegiatan pembelajaran, seperti membuat salinan dokumen otomatis untk siswa, membuat tugas dan langsung menilainya. Kelebihan aplikasi google classroom dibandingkan dengan aplikasi yang lain yaitu aplikasi google classroom ini bisa diakses secara gratis dan dirancang khusus untuk membantu guru atau pengajar dalam pembelajaran. Penelitian terdahulu mengenai penggunaan aplikasi google classroom diantaranya, Diemas Bagas P.P dan Rina Harimurti (2017), menyimpulkan bahwa terdapat perbedaan hasil belajar yang signifikan antara kelas eksperimen yang menggunakan pembelajaran dengan google clasroom dan kelas kontrol yang hanya menggunakan pembelajaran berbasis proyek.

Dengan demikian, tujuan dari penelitian ini adalah untuk mengetahui apakah penggunaan aplikasi google classroom ini dapat meningkatkan hasil belajar matematika. Sehingga hasil penelitian ini juga dapat diketahui hasil peningkatan kemampuan melalui tes yang diberikan. Adapun rumusan masalah penelitian adalah bagaimana penggunaan aplikasi google classroom dapat meningkatkan hasil belajar.

Jenis penelitian yang dilakukan adalah penelitian tindakan kelas yang fokus utamanya adalah untuk meningkatkan hasil belajar siswa dilihat dari keaktifan siswa dan dengan penggunaan aplikasi google classroom dalam pembelajaran matematika.

\section{METODE}

Sumber data penelit adalah siswa kelas IX.2 SMP NEGERI 18 Bengkulu Tahun ajaran 2020/2021 sebanyak 28 siswa, terdiri dari 23 laki-laki dan 5 perempuan. Rencana penelitian yang akan dilaksanakan yaitu membuat kelas di google classroom, memberikan link berupa video materi pembelajaran di google classroom, kemudian siswa belajar dari materi yang diunggah, siswa diberikan kesempatan untuk tanya jawab pada saat kegiatan pembelajaran untuk menilai keaktifan siswa, siswa mengerjakan test 1 dan test 2 untuk mengukur kemampuan hasil belajar siswa.

Penelitian ini menggunakan data kualitatif, yaitu data yang berbentuk kata, kalimat, dan skema. Pengumpulan data dilakukan secara sistematis dan data yang dikumpulkan sesuai dengan masalah yang diteliti. Pengambilan data dilakukan dengan cara :

(1) Observasi yang meliputi:

a) absensi siswa pada saat kegiatan pembelajaran,

b) pengisian angket oleh siswa.

(2) Wawancara, dilakukan terhadap guru matematika.

(3) Dokumentasi.

(4)Tes.(berupa tugas-tugas essay dan objektif) 
Efektifitas pembelajaran berbasis daring (yaitu pembelajaran dengan menggunakan aplikasi google classoroom sebagai media pembelajaran) ditinjau dari dua siklus : Pada siklus I peneliti menggunakan media aplikasi gogle classroom sebagai media atau referensi untuk belajar matematika. Pada siklus ini peneliti melakukan kegiatan pembelajaran dengan memberikan video pembelajaran serta tanya jawab mengenai materi yang diberikan dan mengerjakan soal individu. Soal individu yang nantinya akan dijadikan sebagai nilai hasil belajar pada siklus I. Pada siklus II ini peneliti memanfaatkan google classroom sebgaai proyek dalam melakukan kegiatan pembelajaran yaitu, membuat diskusi di aplikasi google classroom, pembuatan tugas dan hasilnya akan ditampilkan langsung pada aplikasi google classroom, dan mengerjakan soal test. Soal test ini sebagai nilai hasil belajar pada siklus II yang sebelumnya sudah disampaikan pada pertemuan sebelumnya. Siswa diharapkan mampu memanfaatkan aplikasi Google Classroom untuk belajar.

Selain itu data peningkatan keaktifan belajar dilihat dari: a) menjawab pertanyaan, b) mengajukan pertanyaan, ide atau gagasan, c) mengerjakan tugas yang diberikan cepat dan tepat waktu. Dari indikator-indikator yang telah disebutkan kemudian dibuat nilai berdasarkan keaktifan belajar siswa. Sedangkan data hasil belajar dikumpulkan melalui metode tes. Tes diberikan siswa untuk menguji seberapa kemampuan siswa dalam memahami pembelajaran matematika. Tes diberikan dua kali yaitu pada siklus 1 dan siklus 2 untuk mengidentifikasi perubahan hasil belajar siswa. Hasil belajar dilihat dari pencapaian siswa terhadap kriteria ketuntasan minimal (KKM $\geq 75)$.

\section{HASIL PENELITIAN DAN PEMBAHASAN}

Pembahasan terhadap permasalahan maupun hipotesis tindakan berdasarkan analisis data kualitatif. Uraian pada pembahasan ini dibagi menjadi dua bagian, bagian pertama mengungkap temuan penelitian berdasarkan hasil data yaitu hasil belajar dan keaktifan. Sedangkan bagian kedua diskusi tentang hubungan hasil penelitian dengan penelitian terdahulu yang terkait.

Setelah diadakan penelitian diperoleh hasil, ada peningkatan hasil belajar matematika. Tindakan yang dilakukan melalui penggunaan aplikasi google classroom untuk meningkatkan hasil belajar siswa. Tujuannya adalah agar mempermudah siswa untuk belajar secara efektif dan efisien, aktif, menciptakan susasana pembelajaran yang baru dan memperkenalkan siswa pembelajaran daring.

Tabel 1. Peningkatan Hasil Belajar Pada Setiap Siklus

\begin{tabular}{|c|c|c|c|}
\hline Keterangan & \multirow{2}{*}{$\begin{array}{l}\text { Sebelum } \\
\text { tindakan }\end{array}$} & \multicolumn{2}{|c|}{ Setelah tindakan } \\
\cline { 3 - 4 } & & Siklus I & Siklus II \\
\hline Siswa mencapai Kriteria & 12 siswa & 18 siswa & 23 siswa \\
Ketuntasan Minimal (KKM) & $(42,9 \%)$ & $(64,3 \%)$ & $(82,1 \%)$ \\
\hline Siswa yang tidak mencapai Kriteria & 16 siswa & 10 siswa & 5 siswa \\
Ketuntasan Minimal (KKM) & $(57,1 \%)$ & $(35,7 \%)$ & $(17,9 \%)$ \\
\hline
\end{tabular}

Berdasarkan pada hasil analisis data, tabel 1 menunjukan peningkatan hasil perhitungan disetiap siklus. Terdapat perbedaan jumlah siswa yang mencapai Kriteria Ketuntasan Minimal (KKM) disetiap siklus, dari sebelum dan sesudah penggunaan aplikasi google classroom..Rendahnya nilai siswa sebelum tindakan tersebut dikarenakan kurangnya waktu belajar siswa secara efesien dan siswa kurang memahami materi yang disampaikan, sehingga dengan adanya penggunaan google classroom ini mempermudah siswa untuk belajar. Jumlah siswa yang mencapai Kriteria Ketuntasan Minimal (KKM) adalah 82,1\% atau 23 siswa setelah pengunaan aplikasi google classroom dan 5 siswa $(17,9 \%)$ 
mendapatkan nilai dibawah kriteria ketuntasan minimal (KKM).Jika dibandingkan dengan sebelum penggunaan google classroom yang hanya 12 siswa $(42,9 \%)$ yang mencapai Kriteria Ketuntasan Minimal (KKM) dan 16 siswa $(57,1 \%)$ mendapat nilai dibawah kriteria ketuntasan minimal, maka berdasarkan tabel dapat dilihat presentase ketuntasan siswa mengalami peningkatan (siklus I sebesar $64,3 \%$, siklus II sebesar 82,1\%). Artinya bahwa tingkat keberhasilan dari penggunaan aplikasi google classroom telah memberikan pengaruh yang besar terhadap peningkatan hasil belajar,dengan peningkatannya sebesar $17 \%$ dari sebelumnya.

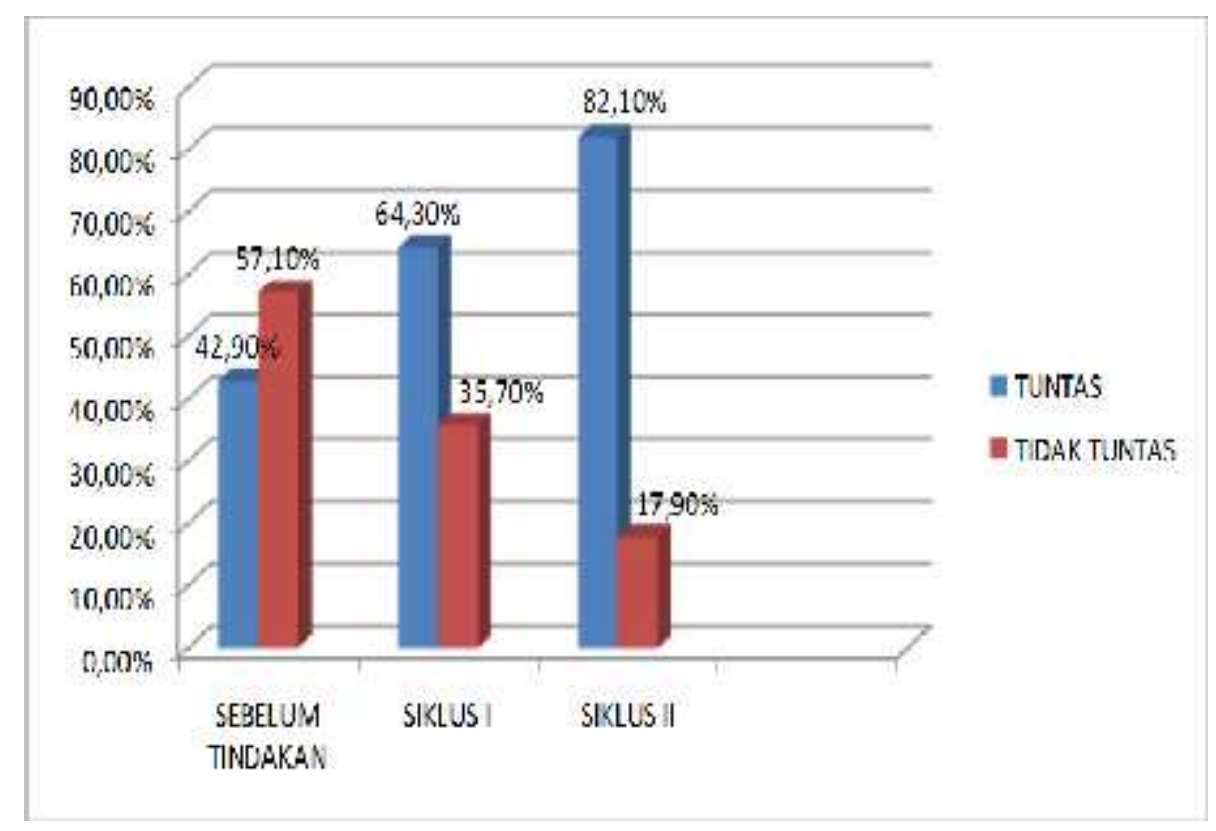

Gambar 1. Grafik Peningkatan Hasil Belajar

Berdasarkan grafik diatas diketahui bahwa siswa yang tuntas Kriteria Ketuntasan Minimal terus meningkat dari sebelum tindakan yang berjumlah 12 siswa $(42,9 \%)$ meningkat menjadi 18 siswa $(64,3 \%)$ pada siklus I kemudian meningkat lagi menjadi 23 siswa $(82,1 \%)$ pada siklus II. Proses meningkatnya per siklus dilihat dari nilai hasil soal individu pada siklus I kemudian dilihat dari nilai kuis yang dilaksanakan pada siklus II. Dari hasil siklus I dan siklus II mengalami peningkatan. Dari hasil diatas dapat disimpulkan bahwa penggunaan media aplikasi google classroom dapat meningkatkan hasil belajar matematika siswa kelas IX.2 SMP Negeri 18 Kota Bengkulu.

Setelah dilakukan penelitian diperoleh hasil, ada peningkatan siswa pada keaktifan belajar matematika. Tindakan yang dilakukan untuk meingkatkan keaktifan belajar siswa yaitu dengan mengukur seberapa aktif siswa dalam proses kegiatan pembelajaran. Tujuannya adalah untuk menciptakan suasana pembelajaran yang menarik, aktif, dan menyenangkan sehingga ada kemauan siswa untuk belajar. Peningkatan keaktifan belajar dilihat dari : a) menjawab pertanyaan, b) mengajukanpertanyaan, ide atau gagasan, c) menyanggah atau menyetujui ide siswa yang lain.d. respon angket yang diberikan pada siswa. Dari indikator- indikator yang telah disebutkan kemudian dibuat nilai berdasarkan keaktifan belajar siswa. Dari hasil nilai itulah siswa dikategorikan siswa sangat aktif, siswa aktif, dan siswa yang tidak aktif. Berikut ini adalah data hasil nilai yang diperoleh selama tindakan kelas yang dilakukan terjadi peningkatan keaktifan siswa. 
Tabel 2. Peningkatan Keaktifan Belajar

\begin{tabular}{|c|l|l|l|}
\hline \multirow{2}{*}{ Keterangan } & Sebelum tindakan & \multicolumn{2}{|c|}{ Setelah tindakan } \\
\cline { 3 - 4 } & & Siklus I & Siklus II \\
\hline $\begin{array}{c}\text { Siswa yang sangat aktif dalam } \\
\text { pembelajaran }\end{array}$ & 4 siswa (14,3\%) & 7 siswa (25\%) & 9 siswa (32,1\%) \\
\hline $\begin{array}{c}\text { Siswa yang aktif dalam } \\
\text { pembelajaran }\end{array}$ & 10 siswa (35,7\%) & 13 siswa (46,4\%) & 15 siswa (53,6\%) \\
\hline $\begin{array}{c}\text { Siswa yang tidak aktif dalam } \\
\text { pembelajaran }\end{array}$ & 14 siswa (50\%) & 8 siswa (28,6\%) & 4 siswa (14,3\%) \\
\hline
\end{tabular}

Berdasarkan tabel diatas dapat pembelajaran matematika dari sebelum dikemukakan bahwa terjadi peningkatan tindakan kelas hingga setelah dilakukan keaktifan siswa terhadap siswa kelas IX.2 tindakan kelas. SMP Negeri 18 Kota Bengkulu, dalam



Gambar 2. Data presentase peningkatan keaktifan siswa dalam proses pembelajaran

Dari grafik di atas dapat dilihat bahwa dalam proses pembelajaran setiap siklusnya mengalami peningkatan dari sebelum tindakan sampai siklus ke-II. Pada siklus I siswa yang sangat aktif dalam proses pembelajaran mengalami peningkatan sebesar $10,7 \%$,siswa yang aktif dalam proses pembelajaran mengalami peningkatan sebesar $10,7 \%$, dan siswa yang tidak aktif mengalami penurunan sebesar $21,4 \%$.

Pada siklus II, siswa yang sangat aktif mengalami peningkatan $7,1 \%$ jika dibandingkan dengan siklus I (siklus II sebesar $32,1 \%$, siklus I sebesar $25 \%$ ), siswa yang aktif mengalami peningkatan sebesar $7,2 \%$ jika dibandingkan dengan siklus I (siklus II sebesar 53,6\%, siklus I sebesar $46,4 \%$ ), dan siswa yang tidak aktif mengalami penurunan sebesar 14,3\% jika dibandingkan siklus I (siklus II sebesar $28,6 \%$ siklus I sebesar 14,3\%).

Dari hasil data diketahui bahwa diterapkannya metode pembelajaran berbasis daring yaitu dengan penggunaan aplikasi google classroom cukup efektif untuk melengkapi implementasi dari pendekatan pembelajaran. Tahapan implementasi ini telah di sesuaikan dengan pendekatan pembelajaran yang digunakan selama ini, yaitu pendekatan kontekstual. Karena dalam memahami suatu materi pembelajaran harus mengetahui konteks dari inti setiap materi yang dipelajari sehingga materi yang di sampaikan dapat diterima oleh siswa. Langkah pertama, membuat materi bahan ajar yang telah disesuaikan secara jelas dan dapat dipahami oleh siswa, sehingga siswa dapat belajar dengan mudah. Kemudian 
mengunggah materi tersebut ke dalam aplikasi google classroom. Materi tersebut tentang bacaan pembelajaran matematika dalam bentuk word ataupun pdf dan video tentang pembelajaaran matematika sebagai referensi siswa untuk belajar. Di aplikasi google classroom juga disediakan kolom komentar yang bertujuan untuk membuka ruang diskusi antara pengajar dan siswa. Sehingga siswa dapat bertanya dengan mudah tentang materi yang dianggap sulit. Selanjutnya untuk proses pembelajaran di kelas disesuaikan dengan pendekatan kontekstual melalui aplikasi google classroom.

Kegiatan pembelajaran tersebut cukup efektif, karena berbagai macam referensi untuk belajar sudah diunggah ke aplikasi google classroom, sehingga siswa dapat belajar dengan mudah. Selain itu siswa juga merasa senang dan nyaman dengan adanya kemudahan mengakses materi pembelajaran. Secara keseluruhan setelah diterapkannya pembelajaran matematika berbasis daring yaitu dengan penggunaan aplikasi google classroom dapat meningkatkan hasil belajar siswa. Peningkatan di setiap siklus dapat dilihat berdasarkan nilai hasil belajar dengan Kriteria Ketuntasan Minimal ( $\geq 75$ ).

Hasil penelitian ini sesuai dengan pendapat beberapa ahli ataupun penelitian sebelumnya. Penggunaan aplikasi Google Classroom dapat meningkatkan hasil belajar matematika pada siswa kelas IX.2 SMP Negeri 18 Kota Bengkulu. Kegiatan pembelajaran juga dapat meningkatkan keaktifan siswa dalam belajar. Hal ini mendukung diterimanya hipotesis penelitian tindakan kelas yaitu penggunaan aplikasi Google Classroom dapat meningkatkan hasil belajar matematika siswa.

\section{SIMPULAN}

Berdasarkan hasil penelitian maka dapat disimpulkan bahwa pembelajaran daring dengan menggunakan aplikasi google classroom dapat meningkatkan hasil belajar siswa. kelas IX.2 SMP Negeri 18 Kota Bengkulu.

\section{REFERENSI}

Anurrahman. (2009). Belajar dan Pembelajaran. Bandung: Alfabeta.

Depdiknas. (2003). Undang-undang RI No.20 tahun 2003 tentang sistem pendidikan nasional.

Diemas, P.P \& Harimurti, R. (2017). "Pengaruh Penerapan Tools Google Clasroom Pada Model Pembelajaran Project Based Learning Terhadap Hasil Belajar Siswa." Jurnal IT-Edu 2(1), 5967.

Gheytasi, M., Azizifar, A., \& Gowhary, H. (2015). The Effect of Smartphone on the Reading Comprehension Proficiency of Iranian EFL Learners. Procedia Social and Behavioral Sciences, 199, 225-230.

https://doi.org/10.1016/J.SBSPRO.2015.0 7.510

Hardiyana, A. (2015). Implementasi Google Classroom sebagai Alternatif dalam Meningkatkan Mutu Pembelajaran di Sekolah. Karya Tulis Ilmiah, Cirebon : SMA Negeri 1 Losari.

Izenstark, A., \& Leahy, K.L. (2015). "Google Classroom for Librarians : Features and Opportunities." Library $\mathrm{Hi}$ Tech News $32 \quad$ (9):1-3. https://doi.org/10.1108/LHTN-05-20150039.

Kayatun, S. (2014). "Penggunaan Metode Kerja Kelompok untuk Meningkatkan Hasil Belajar Matematika Sekolah Dasar." Jurnal Pendidikan dan Pembelajaran, 3(4).

Keengwe, J., \& Georgina, D. (2012). The digital course training workshop for online learning and teaching. Education and Information Technologies, 17(4), 365-379. https://doi.org/10.1007/s10639011-9164

Rozak,A \& Albantani,AM. (2018). Desain Perkuliahan Bahasa Arab Melalui Google Classroom . Jurnal Pendidikan Bahasa Arab dan Kebahasaaraban 5(1), 83-102. 